\title{
PENANAMAN NILAI-NILAI NASIONALISME PADA GENERASI MUDA DI KEPULAUAN NATUNA
}

\author{
Endang Susilowati, Dhanang Respati Puguh, Noor Naelil Masruroh \\ Fakultas Ilmu Budaya Universitas Diponegoro \\ Jl. Prof. H. Soedarto, SH Tembalang Semarang 50275 \\ Email: endangsusilowati@undip.ac.id
}

\begin{abstract}
This study aims to reveal the portrait of nationalism and explore the noble values and local wisdom of Natuna's inhabitant that can strengthen the sense of nationalism. The method used in this article is historical method and ethnography. The result shows that the sense of nationalism of Natuna's inhabitant who's living in the outer islands is undoubtable, even though they are far away from the center of government, lack of attention, and therefore they are still left behind. In order to fortify their spirit of nationalism and their pride to the region and country, it is necessary to continuously instill national values to the younger generation in Natuna.
\end{abstract}

Keywords: outer islands, sense of nationalism, noble values, local wisdoms

\section{PENDAHULUAN}

Permasalahan yang dihadapi negara kepulauan yang terdiri dari beragam etnis, agama, dan budaya seperti Indonesia adalah sulitnya menjaga keutuhan wilayah, integrasi nasional, dan keharmonisan sosial dalam masyarakatnya. Permasalahan itu semakin mencuat di pulau-pulau terdepan, terpencil, dan tertinggal. Kurangnya perhatian pemerintah terhadap kesejahteraan penduduk di pulau-pulau tersebut menjadi salah satu penyebab semakin meningkatnyaancaman terhadap integrasi nasional. Kondisi tersebut diperparah dengan masih minimnya upaya pemerintah untuk membenahi permasalahan yang muncul berdasar pada pendekatan yang tepat dan sistematis.

Nasionalisme yang melemah
menjadi isu hangat yang
diperbincangkan ketika ada sebagian
penduduk pulau terdepan yang
memutuskan untuk mencari
perutungan hidup lebih baik ke negara
tetangga dan untuk itu tidak jarang
mereka rela mengganti
kewarganegaraannya. Tentu saja
mereka tidak dapat disalahkan atas
pilihan yang diambilnya.Akan tetapi
kejadian seperti itu tentu menjadi
pukulan berat bagi Negara, apalagi jika
kejadian itu menjadi sebuah gerakan
massal. Oleh karena itu kepekaan
pemerintah terhadap isu-isu sosial
ekonomi di daerah terdepan, yang
notabene merupakan representasi
"wajah negara", dan bahkan menjadi
pintu gerbang negara dalam


berhubungan dengan negara lain, menjadi sebuah keharusan yang tidak bisa ditawar-tawar lagi.

Natuna merupakan kabupaten paling utara di Indonesia yang berada dalam wilayah Provinsi Kepulauan Riau.Wilayah Kabupaten Natuna terdiri dari dua gugusan pulau, yaitu gugusan Pulau Natuna (Bunguran, Sedanau, Midai, Pulau Laut, dan Pulau Tiga) dan gugusan Pulau Serasan (Pulau Serasan, Subi Besar, dan Subi Kecil) (BPS Kabupaten Natuna, 2012: 7). Sebagai kabupaten paling utara, Natuna berbatasan dengan beberapa negara tetangga, yaitu Vietnam, Kamboja, Thailand, Singapura, dan Malaysia. Secara geografis, jarak Natuna dengan Malaysia (Kuching) jauh lebih dekat (sekitar $350 \mathrm{~km}$ ) dibandingkan dengan Jakarta $(1.135,628 \mathrm{~km}) \quad$ (BPS Kabupaten Natuna, 2012: 7: 18). Kedekatan letak geografis Natuna dengan negara tetangga, khususnya Malaysia, dan kemudahan untuk mencapainya, bukan tidak mungkin akan membawa konsekuensi melemahnya nasionalisme penduduk. Hal itu masih ditambah dengan kenyataan bahwa pembangunan yang dicanangkan pemerintah pusat belum banyak menyentuh pulau-pulau terdepan. Keadaan infrastruktur dan suprastruktur di beranda terdepan Indonesia itu masih jauh tertinggal dari daerah-daerah lain, terutama Jawa. Bila rasa nasionalisme penduduktidak dibentengi dengan baik, tidak mustahil dapat mengancam integrasi nasional.

Artikel ini bertujuan untuk mengetahui apakah rasa nasionalisme masyarakat Natuna tidak terusik oleh kenyataan bahwa mereka sangat jauh dari pusat kekuasaan Indonesia dan kurang mendapat perhatian yang semestinya dari pemerintah pusat. Selain itu juga akan diungkapkan bagaimana usaha masyarakat Natuna untuk tetap menjaga nilai-nilai nasionalisme dan rasa cinta mereka terhadap tanah air Indonesia.

\section{METODE}

Penelitian ini memadukan metode sejarah dan metode etnografi. Metode sejarah digunakan untuk mengungkap latar belakang sejarah dan perkembangan Kabupaten Natuna yang merupakan hasil pemekaran dari Kabupaten Kepulauan Riau pada tahun 1999. Metode sejarah dilakukan melalui empat tahap, yaitu pengumpulan sumber, kritik sumber, interpretasi, dan historiografi. Pengumpulan sumber antara lain dilakukan melaui studi arsip, studi pustaka, metode sejarah lisan, dan penyebaran kuesioner kepada para responden untuk mendapatkan gambaran tentang persepsi dan sikap masyarakat terhadap masalah nasionalisme. Sementara itu metode etnografi digunakan untuk mendapat gambaran tentang berbagai suku atau etnis yang berdomisili di Kabupaten Natuna dengan berbagai permasalahan sosial budaya yang menyertainya.

\section{HASIL DAN PEMBAHASAN}

\subsection{Profil Kabupaten Natuna}

Kabupaten Natuna terletak di ujang utara Kepulauan Indonesia, di antara laut Natuna dan Laut Cina Selatan. Letak Natuna sangat strategis karena berada di jalur pelayaran internasional, tempat bertemunya kepentingan berbagai negaraterutama 
karena adanya sumber daya alam yang sangat besar, baik berupa sumber daya hayati maupun sumber energi yang terkandung di dalamnya. Kabupaten Natuna berbatasan dengan Vietnam dan Kamboja di sebelah utara, Laut Natuna di sebelah selatan, Malaysia Timur dan Kalimantan Barat di sebelah timur, dan Semenanjung Malaysia di sebelah barat.Kabupaten Natuna memiliki luas wilayah $264.198,37 \mathrm{~km}^{2}$ yang terdiri dari daratan seluas $2.001,30 \mathrm{~km}^{2}$ dan lautan seluas 262.197,07 $\mathrm{km}^{2}$, dengan jumlah penduduk sebanyak 76.305 jiwa (BPS Kabupaten Natuna, 2012: 6, "Sosial Budaya Kabupaten Natuna”...)

Wilayah Kabupaten Natuna mencakup 157 pulau, 30 pulau diantaranya berpenghuni dan sisanya sekitar 127 pulau merupakan pulau yang tidak berpenghuni. Di antara gugusan pulau-pulau itu terdapat dua pulau besar, yaitu Pulau Bunguran dan Serasan. Pulau-pulau di Kabupaten Natuna dikelompokkan dalam dua gugusan pulau, yaitu gugusan pulau Natuna yang meliputi Sedanau, Midai, Pulau Laut, dan Pulau Tiga; serta gugusan pulau Serasan yang meliputi Serasan, Subi Besar, dan Subi Kecil. Selain itu, di Kabupaten Natuna terdapat pemukiman khusus kaum transmigran yang terdiri dari Satuan Pemukiman (SP) I, II, dan III yang berlokasi di Kecamatan Bunguran Tengah.

Secara administratif Kabupaten Natuna termasuk dalam wilayah Provinsi Kepulauan Riau. Kabupaten ini baru dibentuk pada tahun 1999 sebagai hasil pemekaran Kabupaten
Kepulauan Riau berdasar pada UU No. 53 Tahun 1999, yang menyebutkan Kabupaten Kepulauan Riau (Kabupaten Bintan), Kabupaten Karimun, dan Kabupaten Natuna sebagai daerah otonom. Pada tahun 2007, Natuna memiliki 16 kecamatan yang terdiri dari 75 desa, tetapi dengan adanya pembentukan Kabupaten Anambas pada tahun 2008, maka wilayah Kabupaten Natuna berkurang dan sampai saat ini tersisa 12 kecamatan, terdiri dari dengan 6 kelurahan dan 67 desa (BPS Kabupaten Natuna, 2012: 7) Kabupaten Natuna memiliki dua buah kota kecamatan, yakni Kota Sedanau sebagai ibukota Kecamatan Bunguran Barat dengan luas $216,65 \mathrm{~km}^{2}$ dan Kota Ranai sebagai ibukota Kecamatan Bunguran Timur sekaligus sebagai ibukota Kabupaten Natuna dengan luas $250 \mathrm{~km}^{2}$.

Penduduk Kabupaten Natuna tercatat sebanyak 72.950 jiwa pada tahun 2011. Jumlah itu terdiri dari 37.158 laki-laki dan 35.792 perempuan. Menurut BPS Kabupaten Natuna, tingkat pertumbuhan penduduk di daerah ini sebesar 2,79\% pada tahun 2012. Terjadinya peningkatan jumlah penduduk di Kabupaten Natuna saat ini didukung oleh arus migrasi barang dan manusia. Meskipun demikian pertumbuhan penduduk Natuna relatif lebih rendah dibandingkan dengan Kabupaten lain di provinsi Kepulauan Riau yang ratarata mencapai $5,03 \%$. Tabel 1 di bawah inimenunjukkan komposisi jumlah di Kabupaten Penduduk Natuna menurut kecamatan pada tahun 2012. 
Tabel 1. Jumlah Penduduk Kabupaten Natuna Tahun 2012

\begin{tabular}{lccc}
\multicolumn{1}{c}{ Kecamatan } & \multicolumn{2}{c}{ Jumlah Penduduk } & \multirow{2}{*}{ Total } \\
& Laki-Laki & Perempuan & \\
\hline Midai & 2.689 & 2.621 & 5.310 \\
Bunguran Barat & 5.856 & 5.700 & 11.556 \\
Bunguran Utara & 2.011 & 1.973 & 3.984 \\
Pulau Laut & 1.178 & 1.084 & 2.262 \\
Pulau Tiga & 2.634 & 2.398 & 5.032 \\
Bunguran Timur & 12.423 & 11.958 & 24.381 \\
Bunguran Timur Laut & 2.277 & 2.217 & 4.494 \\
Bunguran Tengah & 1.515 & 1.442 & 2.957 \\
Bunguran Selatan & 1.336 & 1.311 & 2.647 \\
Serasan & 2.422 & 2.366 & 4.788 \\
Subi & 1.373 & 1.317 & 2.690 \\
Serasan Timur & 1.444 & 1.405 & 2.849 \\
\hline \multicolumn{1}{c}{ Total } & 37.158 & 35.792 & 72.950 \\
\hline
\end{tabular}

Sumber: BPS Kabupaten Natuna, 2012.

Tabel 1 di atas menunjukkan bahwa Kecamatan Bunguran Timur tercatat sebagai daerah yang memiliki tingkat kepadatan penduduk tertinggi dengan 24.381 jiwa yang diikuti dengan Kecamatan Bunguran Barat sebesar 11.556 jiwa. Hal ini disebabkan pusat pemerintahan dan ibukota Kabupaten Natuna terletak di Kecamatan Bunguran Timur. Demikian pula dengan Kecamatan Bunguran Barat dengan kota Kecamatan Sedanau, daerah ini merupakan daerah ramai karena arus barang-barang kebutuhan sehari-hari penduduk Natuna terkadang dipasok melalui daerah ini.
Penduduk Natuna sebagian besar adalah etnis Melayu, mereka tersebar di seluruh penjuru Natuna atau sekitar $92 \%$ dari keseluruhan jumlah penduduk. Di samping etnis Melayu, di Natuna juga terdapat etnis Jawa, Bugis, Batak, dan Minang. Menurut Wan Zawali sebagai ketua Lembaga Adat Melayu (LAM), penduduk Melayu menerima keberadaan suku lain di tanah Melayu dengan terbuka. Oleh karena itu sampai saat ini di Kabupaten Natuna hampir tidak pernah terjadi konflik antar suku. Masing-masing komposisi etnis tersebut dapat dilihat pada gambar di bawah ini. 
HUMANIKA Vol. 19 No. 1 (2014) ISSN 1412-9418

Penanaman Nilai-Nilai Nasionalisme pada Generasi Muda

Endang Susilowati, Dhanang Respati Puguh, Noor Naelil Masruroh

Gambar 1. Persentase Jumlah Etnis di Kabupaten Natuna

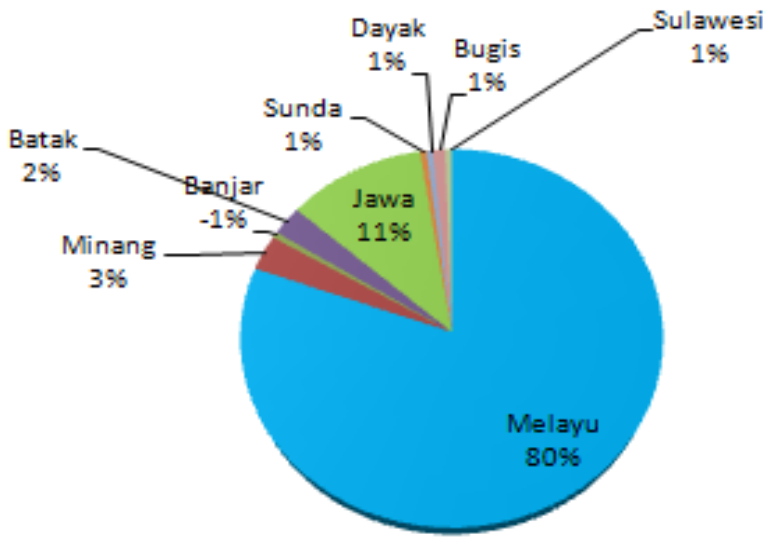

Sumber: Diolah dari data Bappeda Kabupaten Natuna, 2012.

Diagram di atas menunjukkan bahwa kondisi masyarakat Natuna yang multietnik tidak menjadi kendala untuk membina kerukunan masyarakat baik dalam bidang ekonomi maupun budaya. Etnis pendatang melakukan asimilasi dan adaptasi dengan kebudayaan masyarakat Melayu. Dalam persoalan pemukiman, di Natuna masih tampak pengelompokan pemukiman terutama untuk etnis Jawa dan Cina. Etnis Jawa mayoritas adalah para transmigran, mereka mendapat area khusus pemukiman yang dikenal dengan sebutan SP I, II, III yang terletak di Kecamatan Bunguran Tengah.

\subsection{Potret Nasionalisme \\ Masyarakat Kabupaten Natuna}

Menurut keterangan dari beberapa informan, walaupun berbatasan wilayah laut dengan beberapa negara, melakukan aktivitas ekonomi dengan warga negara tetangga, dan banyak menggunakan produk-produk luar negeri khususnya Malaysia dalam pemenuhan kehidupan sehari-hari, tampaknya belum ada persoalan yang cukup serius berkaitan dengan nasionalisme masyarakat Kabupaten Natuna. Setidaknya hal ini tercermin dengan adanya slogan yang berbunyi: "NKRI Harga Mati" yang terdapat di lingkungan Sekolah Menengah Kejuruan Negeri (SMKN) 1 Kabupaten Natuna. Keberadaan slogan itu merefleksikan adanya keinginan yang tidak dapat ditawar-tawar lagi dari sebagian masyarakat Kabupaten Natuna untuk tetap menjadi bagian dari Negara Kesatuan Republik Indonesia, sekaligus merupakan upaya untuk menanamkan rasa kebangsaan dan cinta tanah air kepada siapa yang membacanya, khususnya siswa-siswi SMKN 1. Fakta ini juga dikuatkan oleh keterangan dari Wan Zawali, Ketua Lembaga Adat Melayu, yang menyatakan bahwa di kalangan 
masyarakat bawah tidak ada keinginan sama sekali untuk berpindah ke Malaysia, apalagi Vietnam. Namun tidak dapat dimungkiri, menurut pengamatannya, sekarang ini sedang terjadi penurunan rasa kebangsaan yang ditunjukkan oleh adanya perilaku para pemimpin Kabupaten Natuna yang kurang amanah terhadap jabatan yang telah diembannya.

Namun demikian, di sisi lain capaian tingkat kemajuan Natuna setelah hampir 14 tahun menjadi Kabupaten Natuna, ketidakadilan ekonomi, dan posisinya yang berbatasan dengan wilayah laut negara lain merupakan persoalan yang dewasa ini dianggap dapat memerosotkan nilai-nilai nasionalisme masyarakat Natuna sekaligus ancaman bagi integrasi nasional. Menurut keterangan beberapa informan, kondisi Kabupaten Natuna yang masih belum maju dibandingkan dengan kabupatenkabupaten lainnya, persoalan pembagian konsesi minyak dan gas di blok Natuna yang dianggap tidak adil, dan perhatian yang kecil dan kekurangberpihakan pemerintah pusat terhadap Kabupaten Natuna dianggap oleh sebagian masyarakat Natuna sebagai persoalan yang dapat merongrong nasionalisme masyarakat Natuna. Kondisi-kondisi ini dapat memunculkan keinginan untuk memisahkan diri dari Negara Kesatuan Republik Indonesia, apabila tidak segera mendapatkan perhatian.

Menurut sebagian elite partai politik di Kabupaten Natuna, merealisasikan keinginan untuk memisahkan diri atau bergabung dengan negara lain merupakan persoalan yang mudah bagi masyarakat Kabupaten Natuna. Secara Hukum Laut Internasional wilayah Natuna lebih mudah lepas dari Indonesia daripada Aceh atau Papua Barat. Hal ini didasari oleh argumen berikut ini. Di wilayah Natuna tidak ditemukan satu pun mercusuar peninggalan Belanda atau Inggris yang dapat digunakan untuk membuktikan bahwa wilayah ini adalah wilayah Hindia Belanda. Natuna menjadi bagian dari wilayah Indonesia berdasar Traktat London. Perjanjian antara Inggris dan Belanda yang menurut sebagian elit di Kabupaten Natuna tidak pernah melibatkan nenek moyang mereka. Masyarakat Kabupaten Natuna dapat menggaungkan persoalan ini di Makamah Internasional untuk mendapatkan perhatian dunia. Setelah mendapat perhatian di Mahkamah Internasional, maka masyarakat Kabupaten Natuna dapat memanfaatkan hukum laut, bahwa laut Natuna adalah Alur Laut Kepulauan Indonesia (ALKI). Dengan memanfaatkan ALKI masyarakat Natuna dapat mengundang kapal induk Amerika Serikat untuk melewati ALKI dan berhenti. Indonesia tidak boleh mengganggu keberadaan kapal induk Amerika Serikat selagi kapalinduk itu tidak menggelar peralatan perangnya. Kalau kapal induk Amerika Serikat berada di ALKI, maka Indonesia akan gelisah dan akan menurunkan Tentara Nasional Indonesia di Natuna. Pasukan yang paling banyak diturunkan adalah Angkatan Darat, karena Angkatan Laut Indoneisia tidak kuat. Dengan banyaknya tentara berada di Natuna, akan menggelisahkan orang-orang kampung, karena pernah ada kejadian mereka mengganggu anak gadis dan istri orang-orang kampung. Dengan kegelisahan itu elit di Kabupaten Natuna dapat memprovokasi 
HUMANIKA Vol. 19 No. 1 (2014) ISSN 1412-9418

Penanaman Nilai-Nilai Nasionalisme pada Generasi Muda

Endang Susilowati, Dhanang Respati Puguh, Noor Naelil Masruroh

masyarakat untuk meninggalkan pulau ini dengan menggunakan pompongpompong (perahu-perahu) melakukan eksodus ke kapal induk Amerika Serikat. Oleh karena kapal adalah wilayah sebuah negara berdaulat berdasarkan bendera kebangsaan yang dikibarkan, maka orang-orang Kabupaten Natuna sudah berada di wilayah Amerika Serikat walaupun kapal induk itu berada di perairan Indonesia. Para elit di Kabupaten Natuna dapat mengundang Dewan Keamanan Perserikatan BangsaBangsa dan Makamah Internasional untuk melakukan referendum. Dengan referendum di kapal induk itu, maka Amerika Serikat akan menjadi negara pertama yang mengesahkannya. Dengan skenario semacam itu, sebenarnya merealisasikan keinginan untuk melepaskan diri dari Indonesia sangat mudah tanpa adanya pergolakan.

Terlepas dari kebenaran logika yang dibangun dalam argumen di atas, secara riil keinginan untuk memisahkan diri merupakan wacana yang selalu digulirkan oleh sebagian elit partai politik di Kabupaten Natuna untuk meningkatkan posisi tawar mereka ketika sedang bernegosiasi dengan pemerintah pusat. Namun demikian, persoalan-persoalan tersebut perlu mendapatkan perhatian dan antisipasi dari pemerintah pusat. Peningkatan kemajuan Kabupaten Natuna dan kesejahteraan warga masyarakatnya merupakan salah satu jawaban untuk mempertahankan semangat nasionalisme masyarakat Natuna yang sekaligus dapat mengeliminasi keinginan-keinginan untuk memisahkan diri atau menjadi bagian dari negara lain yang bertetangga dengan Indonesia.
Salah satu solusi untuk mengatasi persoalan itu adalah pemekaran Natuna menjadi provinsi dengan membentuk kabupatenkabupaten baru di Natuna. Menurut Rondial, yang menjadi salah satu ketua tim pemekaran kabupaten baru di Natuna, walaupun berdasar peraturan pemerintah pemekaran wilayah tidak memenuhi syarat, tetapi pemekaran Natuna perlu untuk dilakukan. Kabupaten Natuna perlu dimekarkan menjadi beberapa kabupaten, supaya Natuna segera dapat menjadi provinsi. Tujuannya agar di perbatasan ini ada eselonisasi pemerintahan yang tinggi, sehingga persoalan-persoalan khususnya yang timbul dari perbatasan wilayah lautan dapat segera diselesaikan. Natuna memerlukan kehadiran negara yaitu dengan adanya pejabat-pejabat tingkat provinsi yang bertanggung jawab terhadap kedaulatan negara di wilayah perbatasan. Dengan demikian, apabila terjadi pelanggaran terhadap wilayah perbatasan laut dapat diselesaikan dengan segera. Hal ini perlu dilakukan mengingat Natuna menjadi pintu gerbang terpenting, karena merupakan satu-satunya kabupaten di Indonesia yang berbatasan dengan beberapa negara. Negara-negara yang berbatasan dengan Kabupaten Natuna hampir semuanya agresif. Cina adalah negara yang agresif dalam kemiliteran. Ia memiliki kapal induk dan mengklaim 1000 mil dari pantainya adalah wilayahnya termasuk Natuna. Thailand dan Vietnam adalah negara yang agresif dalam bidang perikanan, sehingga nelayan-nelayan mereka sering melampaui batas perairan wilayah Indonesia. Sementara itu, Malaysia merupakan negara yang agresif dalam bidang perekonomian 
dengan memasarkan produk-produkya ke Natuna. Dengan demikian, pembentukan kabupaten-kabupaten baru untuk mengembangkan Natuna menjadi sebuah provinsi memang harus dilakukan. Secara politis Indonesia harus memanfaatkan Natuna untuk menghadapi negara-negara yang berbatasan langsung dengan Indonesia. Kegiatan latihan perang yang melibatkan 18 negara di perairan Natuna merupakan tindakan yang tepat untuk mempertegas posisi Natuna sebagai bagian dari wilayah Republik Indonesia.

\subsection{Nilai-nilai Kearifan Lokal yang Mendukung Penanaman Nilai- nilai Nasionalisme}

$\begin{array}{ccr}\text { Kearifan } & \text { lokal adalah } \\ \text { "pandangan hidup dan } & \text { ilmu } \\ \text { pengetahuan serta berbagai } & \text { strategi }\end{array}$ kehidupan yang berwujud aktivitas yang dilakukan oleh masyarakat lokal dalam menjawab berbagai masalah dalam pemenuhan kebutuhan mereka". Istilah ini dalam bahasa Inggris dikonsepsikan sebagai local wisdom (kebijakan setempat) atau local knowledge (pengetahuan setempat) atau local genious (kecerdasan setempat). Sistem pemenuhan kebutuhan mereka meliputi seluruh unsur kehidupan: agama, ilmu pengetahuan, ekonomi, teknologi, organisasi sosial, bahasa dan komunikasi, serta kesenian. Mereka mempunyai pemahaman, program, kegiatan, pelaksanaan terkait untuk mempertahankan, memperbaiki, mengembangkan unsur kebutuhan mereka, dengan memperhatikan lingkungan dan sumber daya manusia yang terdapat pada warga mereka ("Memberdayakan Kearifan Lokal..."). Bertolak dari definisi itu, maka kearifan lokal merupakan sesuatu yang berkaitan secara spesifik dengan budaya budaya lokal dan mencerminkan cara hidup suatu masyarakat pada lokalitas tertentu. Dengan kata lain, kearifan lokal bersemayam pada budaya lokal (local culture).

Budaya lokal (juga sering disebut budaya daerah ${ }^{1}$ ) merupakan istilah yang biasanya digunakan untuk membedakan suatu budaya dari budaya nasional (Indonesia) dan budaya global. Budaya lokal adalah budaya yang dimiliki oleh masyarakat yang menempati lokalitas atau daerah tertentu yang berbeda dari budaya yang dimiliki oleh masyarakat yang berada di tempat yang lain. Permendagri Nomor 39 Tahun 2007 pasal 1 mendefinisikan budaya daerah sebagai "suatu sistem nilai yang dianut oleh komunitas/ kelompok masyarakat tertentu di daerah, yang diyakini akan dapat memenuhi harapan-harapan warga masyarakatnya dan di dalamnya

${ }^{1}$ Edi Sedyawati (2007 dan 2008: vi) menyatakan bahwa penggunaan istilah budaya daerah untuk menyebut budaya suku-suku bangsa di Indonesia adalah tidak tepat, karena kata "daerah" mengesankan lawan dari "pusat". Padahal di sini yang diperbedakan adalah budaya bangsa (= nasional) dan budaya suku bangsa. Budaya nasional tentunya tidak dapat disamaartikan dengan budaya pusat, karena ia juga merupakan budaya seluruh bangsa Indonesia, baik di pusat maupun di daerah. Lagi pula suatu budaya suku bangsa tidak dapat dikaitkan secara mutlak dengan satuan daerah administratif, karena ada sejumlah suku bangsa yang tinggal menyebar melintasi batas-batas administratif. 
terdapat nilai-nilai, sikap tatacara masyarakat yang diyakini dapat memenuhi kehidupan warga masyarakatnya" (Dirjen Kesbangpol Depdagri, 2007: 5).

Di Indonesia istilah budaya lokal juga sering disepadankan dengan budaya etnik/ subetnik. Setiap bangsa, etnik, dan sub etnik memiliki kebudayaan yang mencakup tujuh unsur, yaitu: bahasa, sistem pengetahuan, organisasi sosial, sistem peralatan hidup dan teknologi, sistem mata pencaharian, sistem religi, dan kesenian (Koentjaraningrat, 1986: 203204). Namun demikian, sifat-sifat khas kebudayaan hanya dapat dimanifestasikan dalam unsur-unsur terbatas, terutama melalui bahasa, kesenian, dan upacara. Unsur-unsur yang lain sulit untuk menonjolkan sifat-sifat khas kebudayaan suatu bangsa atau suku bangsa (Koentjaraningrat, 1984: 109).

Apa arti penting kearifan lokal dalam penanaman nilai-nilai nasionalisme? Di dalam budaya lokal terdapat gagasan-gagasan (ideas, cultural system), perilaku-perilaku (activities, social system), dan artifak-artifak (artifacts, materialculture) yang mengandung nilai-nilai yang berguna dan relevan bagi penanaman nilai-nilai nasionalisme. Relevansi dan kebergunaan itu terdapat misalnya dalam hal-hal sebagai berikut.

1. Bentuk-bentuk seni tradisi yang berkembang dalam suatu kebudayaan tidak semata-mata diciptakan untuk memenuhi kebutuhan estetis, tetapi untuk memenuhi kepentingan-kepentingan yang didasarkan pada alasan religius, mitos, mata pencaharian, dan integrasi sosial.
2. Nilai budaya dan norma dalam kebudayaan tertentu tetap dianggap sebagai pemandu perilaku yang menentukan keberadaban, seperti kebajikan, kesantunan, kejujuran, tenggang rasa, dan tepa salira.

3. Teknologi beserta teknik-tekniknya dalam praktik dianggap merupakan keunggulan yang dapat dipersandingkan dan dipersaingkan dengan teknologi yang dikenal dalam kebudayaan lain.

4. Suatu rangkaian tindakan upacara tradisi tetap dianggap mempunyai makna simbolik yang dapat diterima meskipun sistem kepercayaan telah berubah. Upacara tradisi juga berfungsi sebagai media integrasi sosial.

5. Permainan tradisional dan berbagai ekspresi folklor lain mempunyai daya kreasi yang sehat, nilai-nilai kebersamaan, dan pesan-pesan simbolik keutamaan kehidupan (Sedyawati, 2008: 280).

Penelusuran nilai-nilai kearifan lokal untuk mendukung penanaman nilai-nilai nasionalisme dilakukan terhadap tunjuk ajar, cerita rakyat, seni pertunjukan dan permainan tradisional masyarakat Melayu Natuna.

Tunjuk ajar adalah segala jenis petuah, amanah, petunjuk, nasihat, amanat, pengajaran, teladan yang bermanfaat bagi kebidupan manusia dalam arti luas. Bagi orang Melayu tunjuk ajar mengandung nilai-nilai luhur agama (Islam) dan norma-norma sosial yang dianut oleh masyarakat Melayu. Tunjuk ajar ditempatkan pada posisi yang penting bagi Masyarakat Melayu. Oleh karena itu, para orang tua pada masyarakat Melayu selalu meng-ingatkan anggota masyarakatnya untuk memelajari dan memahami 
tunjuk ajar dengan sebaik-baiknya. Mereka menya-dari bahwa tanpa tunjuk ajar, banyak nilai-nilai luhur yang terabaikan, bahkan dapat menyebabkan seseorang sesat atau gagal dalam hidupnya. Para orang tua pada masyarakat Melayu senantiasa menganjurkan agar masyarakat jangan lengah, lalai, atau enggan untuk memelajari tunjuk ajar. Mengingat arti penting tunjuk ajar dalam masyarakat Melayu menyebabkan mereka berupaya sekuat tenaga untuk memelajari, memahami, dan mewariskan pada generasi penerus. Tunjuk ajar dianggap bermanfaat bagi pribadi dan masyarakat dalam kehidupan bermasyarakat, berbangsa, bernegara, bahkan dalam kehidupan di akhirat (Effendi, 1994/1995: 5-10).

Salah satu nilai luhur tunjuk ajar Melayu yang relevan untuk digunakan untuk mendukung penanaman nilainilai nasionalisme adalah mengutamakan persatuan dan kesatuan, menjunjung tinggi kegotongroyongan, dan mengekalkan tenggang rasa dalam masyarakat bangsa dan negara. Para orang tua pada masyarakat Melayu menegaskan bahwa rasa persatuan dan kesatuan, kegotongroyongan dan tenggang rasa merupakan inti kepribadian Melayu. Berdasar pada prinsip bahwa hakikat manusia itu adalah bersaudara, bersahabat, dan berkasih sayang, maka tunjuk ajar yang berkaitan dengan persatuan dan kesatuan, kegotongroyongan, dan ketegangrasaan senantiasa hidup dan diwariskan secara turun temurun. Mereka juga menegaskan bahwa prinsip yang dimaksud akan dapat mewujudkan perdamaian.

Dalam salah satu ungkapan adat disebutkan bahwa sikap orang Melayu yang menganggap seluruh manusia bersaudara, karena berasal dari nenek moyang yang sama, yaitu Adam dan Hawa. Oleh karena itu, sudah patut dan selayaknya apabila setiap orang memelihara hubungan baik serta persaudaraan, tanpa memandang asal suku bangsanya. Dalam ungkapan lain dinyatakan dengan tegas adanya rasa persaudaraan. Prinsip inilah yang dijadikan sebagai acuan bagi orang Melayu, sehingga mereka dalam kehidupan senantiasa mencari persahabatan dan perdamaian, saling menghormati, bersikap terbuka, dan selalu berprasangka baik kepada sesama manusia. Prinsip inilah yang menyebabkan para pendatang ke bumi Melayu senantiasa disambut dengan "muka yang jernih dan hati yang suci" yang selanjutnya menumbuhkan keakraban, persatuan tali persaudaraan, dan lain-lain. Hubungan inilah yang melahirkan pluralitas masyarakat dan budaya Melayu.

Salah satu sandaran adat Melayu Riau adalah musyawarah dan mufakat, sesuai dengan ungkapan: "tegak adat karena mufakat, tegak tuah karena musyawarah". Acuan ini menyebabkan mereka sangat menghormati dan menjunjung tinggi musyawarah untuk mufakat dalam kehidupan sehari-hari. Mereka menyadari bahwa tanpa musyawarah dan mufakat, selain dianggap melecehkan adat istiadat, aktiivitas pekerjaan yang dirancang akan mengalami hambatan dan sulit dilaksanakan.

Menurut adat dan tradisi Melayu, apabila tercapai kesepakatan dalam suatu musyawarah, maka kesepakatan itu menjadi tanggung jawab bersama. Siapa yang menyalahi kesepakatan dianggap melanggar adat dan hina dalam pandangan masyarakat, 
sebagaimana ungkapan: "apabila bulat mufakat, berat ringan wajib diangkat; siapa ingkar dari mufakat, tanda dirinya tidak beradat".

Orang Melayu dikenal sebagai orang yang ramah, suka menolong, berprasangka baik, dan amat kokoh memegang tali kekerabatan yang disebut sebagai "tali darah" atau "tali keluarga". Mereka memegang teguh kekeluargaan dan kekerabatan, dan berprinsip bahwa sesama manusia adalah keluarga. Perwujudan sikap hidup bersaudara dengan sesama umat, tercermin dari sikap orang Melayu yang terbuka dan baik terhadap siapa saja yang datang. Perilaku yang menguatkan tali kekerabatan dan kekeluargaan dapat dilihat dari banyaknya orang Melayu yang bersaudara angkat, artinya mereka secara resmi mengaku bersaudara dunia dan akhirat. Para orang tua selalu mengingatkan anak cucunya agar hidup bersaudara dikekalkan tanpa memandang puak dan suku bangsanya. Hal ini setidak-tidaknya dilakukan dengan sikap berbaik-baik dengan siapa saja, berprasangka baik, dan saling menolong. Amanah ini selalu dijadikan sebagai acuan bagi orang Melayu, sehingga mereka mampu hidup berdamping secara rukun dan damai dengan semua pihak.

Kearifan lokal lain yang relevan untuk mendukung penanaman nilainilai nasionalisme adalah amanah yang berkaitan dengan kepemimpinan. Para orang tua Melayu mengatakan: "bertuah ayam ada induknya, bertuah serai ada rumpunnya, bertuah rumah ada tuanya, bertuah kampung ada penghulunya, bertuah negeri ada rajanya, bertuah imam ada jemaahnya". Ungkapan-ungkapan tradisional itu merefleksikan arti penting pemimpin dalam kehidupan manusia. Oleh karena arti penting pemimpin dalam kehidupan manusia dalam berumah tangga, bermasyarakat, ber-bangsa, dan bernegara; maka orang Melayu berusaha untuk mengangkat pemimpinnya yang lazim disebut "orang yang dituakan" oleh masyarakatnya. Pemimpin ini diharapkan mampu membimbing, melindungi, menjaga dan menuntun masyarakat dalam arti yang luas baik untuk kepentingan hidup duniawi maupun akhirat. Pemimpin seperti inilah yang mampu memberikan kesejahteraan lahiriah dan batiniah bagi masyarakat, bangsa, dan negara. Oleh karena pemimpin memegang tanggung jawab yang berat, tugas yang mulia, dan kewajiban yang beraneka macam; maka seorang pemimpin wajib memiliki kepribadian yang baik dan berupaya untuk terus menyempurnakannya. Di dalam tunjuk ajar Melayu disebutkan secara jelas acuan dasar bagi pemimpin, termasuk sifat dan perilakunya, hak dan kewajibannya, dan lain-lain.

Nilai-nilai kearifan lokal yang dapat mendukung penanaman nilai nasionalisme juga terdapat dalam cerita rakyat. Sebagai bagian dari wilayah kebudayaan Melayu, di Kabupaten Natuna banyak berkembang cerita-cerita rakyat. Salah satu di antaranya adalah cerita rakyat Keramat Binjai. Cerita rakyat Keramat Binjai yang berkembang di masyarakat Melayu Natuna, khusus-nya di Bunguran dapat digunakan sebagai sumber nilai untuk acuan berperilaku. Nilai-nilai tersebut antara lain kesabaran, kesetiaan, keikhlasan, dan kepatuhan. Cerita rakyat itu juga mengandung nilai yang dapat mendukung pembentukan jati diri 
masyarakat Melayu Natuna, karena mempunyai nilai keagamaan, pendidikan, moral, dan etika. Bahkan, cerita rakyat yang bertema kepahlawanan itu dapat berguna untuk pembinaan kepribadian bangsa dan berpotensi untuk menjadi filter bagi generasi muda yang cenderung berorientasi mengadopsi unsur-unsur cerita moderen (Nuraini dan Novendra, 2009: 116).

Cerita rakyat Natuna lainnya yang dapat dimanfaatkan untuk penanaman nilai-nilai nasionalisme adalah cerita tentang Nakhoda Saman La'in. Dalam cerita rakyat ini dapat dijumpai cerita kepahlawanan tokohtokoh dari Tanah Melayu pada masa kerajaan, antara lain Datuk Megat Perkasa, Datuk Batin Sabih, dan Datuk Awang Kelana. Mereka adalah saudara seperguruan yang berjuang membela negerinya dalam memerangi perompak-perompak di Laut Cina Selatan (Hilal, 2011).

Seni pertunjukan tradisi Melayu seperti Berdah, Hadrah, Ayam Sudur, Zapin, Kompang/Qasidah tidak hanya berfungsi estetis, tetapi juga sebagai media integrasi sosial. Demikian halnya dengan permainan tradisional gasing, permainan itu tidak hanya sekedar unjuk ketrampilan, tetapi juga menjadi wahana integrasi sosial masyarakat (Kebudayaan dan Cagar Budaya Kab. Natuna, 2010).

Nilai-nilai kearifan lokal yang terdapat dalam tunjuk ajar, cerita rakyat, seni pertunjukan dan permainan tradisional yang berkembang pada masyarakat Melayu Natuna itu akan digunakan sebagai materi dalam penyusunan draf buku ajar penanaman nilai-nilai nasionalisme.

\section{SIMPULAN}

\begin{tabular}{llr}
\multicolumn{1}{c}{ Sebagai } & beranda & terdepan \\
Indonesia, & Kabupaten & Natuna \\
memainkan & peran penting bagi
\end{tabular}
Indonesia. Sumber daya alam di laut Natuna yang melimpah, baik berupa sumber daya hayati maupun gas alam, menyebabkan Natuna banyak dikunjungi oleh berbagai bangsa. Sudah sejak lama masyarakat Natuna termarjinalkan dalam berbagai aspek kehidupan, terutama dalam aspek politik dan ekonomi. Meskipun Natuna merupakan pintu gerbang, halaman depan, atau beranda terdepan Indonesia yang langsung berhadapan dengan beberapa negara tetangga, tetapi pemerintah (terutama pemerintah pusat di Jakarta) masih kurang memberi perhatian semestinya.

Masyarakat Natuna masih menyimpan dan mengamalkan nilainilai luhur peninggalan nenek moyang mereka, serta memiliki banyak kearifan lokal yang menjadi panutan dalam kehidupan sehari-hari. Budaya melayu yang kental dengan nilai-nilai kebersamaan, gotong royong, dan tolong menolong telah menjadi "benteng" kokoh bagi nasionalisme mereka, sehingga nasionalisme masyarakat Natuna tidak perlu diragukan lagi. Meskipun pemerintah abai terhadap kepentingan dan kesejahteraan masya-rakat di ujung utara Indonesia ini dan berbagai kemudahan dapat mereka nikmati dari negara tetangga yang sangat dekat secara geografis, tetapi hal itu tampaknya tidak membuat mereka ingin berpaling dari Negara Kesatuan republik Indonesia (NKRI). 


\section{DAFTAR PUSTAKA}

BPS Kabupaten Natuna. (2012). Natuna Dalam Angka.

Direktorat Jenderal Kesatuan Bangsa dan Politik Departemen Dalam Negeri. (2007). Peraturan Menteri Dalam Negeri Nomor 39 Tahun 2007 tentang Pedoman Fasilitasi Organisasi Kemasyarakatan Bidang Kebudayaan, Keraton, dan Lembaga Adat dalam Pelestarian dan Pengembangan Budaya Daerah.

Din Yusuf, Wan. (2002). Sejarah Bunguran di Kepulauan Natuna.

Effendy, Tenas. (1994/1995). Tunjuk Ajar Melayu (Butir-butir Budaya Melayu Riau). Riau: Proyek Pengembangan Seni Budaya Riau Bappeda Tingkat I Riau.

Hilal, Syamsul. (2011). Nakhoda Saman Lai'in (Cerita Rakyat Natuna). Natuna: Dinas Pemuda, Olahraga, Kebudayaan dan Pariwisata Kabupaten Natuna.

Kebudayaan dan Cagar Budaya Kabupaten Natuna. (2010). Dinas Pemuda, Olahraga, Kebudayaan dan Pariwisata Kabupaten Natuna.

Koentjaraningrat. (1984). Kebudayaan Mentalitas dan Pembangunan. Cetakan ke-11. Jakarta: Gramedia.

"Memberdayakan Kearifan Lokal bagi Komunitas Adat Terpencil", http://www.depsos.go.id/module s.php?name $=$ News\&file $=$ article \&sid=328. Dikunjungi 11 Januari 2010.

Nuraini. (2008). Sejarah Terbentuknya Kabupaten

Natuna. Tanjung-pinang:

Departemen Kebudayaan dan

Pariwisata Balai pelestarian

Sejarah dan Nilai Tradisional

Tanjungpinang.

Nuraini dan Novendra. (2009). Peninggalan Bersejarah Keramat Binjai. NatunaTanjungpinang: Dinas Pemuda, Olah Raga, Kebudayaan dan Pariwisata Kabupaten Natuna dan Balai Pelestarian Sejarah dan Nilai Tradisional Tanjungpinang.

Rohi, Peter A. (2010). Natuna Kapal Induk Amerika. Jakarta: Adibatama Komunika.

Sedyawati, Edi. (2007).

Keindonesiaan dalam Budaya: Buku 1 Kebutuhan Membangun Bangsa yang Kuat. Jakarta: Wedatama Widya Sastra.

Sedyawati, Edi. (2008).

Keindonesiaan dalam Budaya:

Buku 2 Dialog Budaya Nasional dan Etnik, Peranan Industri Budaya dan Media Massa, Warisan Budaya dan Pelestarian Dinamis. Jakarta: Wedatama Widya Sastra.

"Sosial Budaya Kabupaten Natuna", http://www.natunakab.go.id/sosi al-budaya. html. Diunduh pada 20 Juli 2013. 